\title{
Some analytical characters of cottonseed varieties grown in Turkey
}

\author{
By Cevdet Nergiz*, Hasan Yalçin and Hasan Yildiz \\ Celal Bayar University, Faculty of Engineering, Food Engineering Department \\ 45140 Muradiye-Manisa, TURKEY
}

\begin{abstract}
RESUMEN
Algunos caracteres analíticos de variedades de semillas de algodón cultivadas en Turquía

Se han analizado dieciséis variedades de semillas de algodón cultivadas en Turquía. El contenido medio de aceite en las distintas variedades osciló entre $309,7 \mathrm{~g} \mathrm{Kg}^{-1}$ y $379,5 \mathrm{~g} \mathrm{Kg}^{-1}$ mientras que el contenido en gosipol para variedades con glándulas fue desde 7,4 a $12,8 \mathrm{~g} \mathrm{Kg}^{-1}$. Una variedad sin glándula tuvo un valor en gosipol de $0,2 \mathrm{~g} \mathrm{Kg}^{-1}$. El valor en proteínas de las muestras osciló entre 337,2 y $466,5 \mathrm{~g} \mathrm{Kg}^{-1}$. También se determinó la composición en ácidos grasos de los aceites obtenidos de las distintas variedades de semilla de algodón. Por lo general el contenido total en gosipol en las distintas variedades fue inferior a los límites establecidos por algunas naciones para su consumo humano o para alimentación animal.
\end{abstract}

PALABRAS-CLAVE: Composición química - Gosipol Semilla de algodón - Turquía.

\section{SUMMARY}

Some analytical characters of cottonseed varieties grown in Turkey

Sixteen cottonseed varieties grown in Turkey were analysed. The average oil content in varieties ranged from $309.7 \mathrm{~g} \mathrm{Kg}^{-1}$ to $379.5 \mathrm{~g} \mathrm{Kg}^{-1}$ whereas the range in values of gossypol content for glanded varieties was $7.4-12.8 \mathrm{~g} \mathrm{Kg}^{-1}$. One glandless variety contained gossypol as $0.2 \mathrm{~g} \mathrm{Kg}^{-1}$. The samples contained 337.2 $466.5 \mathrm{~g} \mathrm{Kg}^{-1}$ protein. Fatty acid composition of the oils obtained from cottonseed varieties were also determined. Generally total gossypol content of cottonseed varieties were below the limits established by the some nations for human food or animal feed.

KEY-WORDS: Cottonseed - Chemical composition Gossypol - Turkey.

\section{INTRODUCTION}

Cotton is an important agricultural plant in the world because of fibre and seed. It's cultivated mainly for fibre. Total cultivable area are 24.520 .000 hectars in Turkey. Approximately 17 million hectars of it are cultivated. Cotton is grown on 635.000 hectars. Its annual production in the years of 1986-1993 are 932.500 tons in Turkey. After the cotton fibre is removed, cottonseed is obtained as a source of vegetable oil. About 190.000 tons of cottonseed oil is produced each year (1). After oil extraction, the remaining part called cottonseed cake is also excellent source of protein for animals. Cottonseed oil is mainly used for edible purposes. A large portion of it is used in the manufacture of margarine and a small amount is consumed as salad oil in Turkey.

There are numerous cottonseed varieties and species in the world. It was reported that there were two genetically distinct groups in cottonseed varieties known as American and the Asiatic cotton. Cottonseed yields approximately $16 \%$ oil, $45 \%$ meal, $9 \%$ linters (depending on type) and $26 \%$ hull (2). Dehulled cottonseed meal contains about $42 \%$ crude protein and it is used for animal feed (3). On the other hand, cottonseed contains gossypium phenol which is toxic to ruminants (4). It has been reported that gossypol has a contraceptive effect for males in humans and other animal species (5). Gossypol occurs in the pigment glands of the seed and the most remains in the meal after the oil extraction by hexane $(6,7)$. It has been reported that Gossypium hirsutum contains $2.1 \%$ to $4 \%$ gossypol and Gossypium barbadense contains $1.9 \%$ to $3.4 \%$ (8). However, traditional varieties contain about $1 \%$ gossypol (9).

The objective of this study was to determine the content of gossypol protein, crude oil and their fatty acid composition in 16 cottonseed varieties tested newly for adaptation in Turkey.

\section{EXPERIMENTAL}

Cottonseed samples were supplied by the Cotton Research Institute of Nazilli. Fifteen glanded and one glandless varieties of cottonseed grown in adaptation trials in Nazilli were used in the present study. 
For the analysis, lint and hulls were removed from cottonseed samples and meals were used. Nitrogen determination was carried out by the standard Kjeldahl method (10). Digestion and distillation were on the Kjeltec apparatus (model Gerhardt Vapodest 30 ). Crude protein was calculated by multiplying the nitrogen content by the factor 6.25.

Total fat content was obtained by the Soxhlet extraction method using $n$-hexane as described by IUPAC Method 1.122 (11). Fatty acid methyl esters were prepared by methylation of the lipids according to IUPAC Method 2.301 (11). Gas chromatography of the methyl esters was conducted on a Pye Unicam (Model 204) equipped with a hydrogen flame ionization detector. The carrier gas was nitrogen at a flow rate of $30 \mathrm{ml} / \mathrm{min}$. A glass column, of $200 \times 0.5 \mathrm{~cm} \mathrm{o.d.,}$ packed with DEGS $10 \%$ on $80-100$ mesh Chromosorb was used for fatty acid analysis. The column temperature was $180^{\circ} \mathrm{C}$. The peak areas was integrated using a Hewlett-Packard PC integrator.

Total gossiypol content of cottonseed samples were determined using the standard American Oil and Chemists'Society (AOCS) Methods $(12,13) \mathrm{Ba} 8-55$ and $\mathrm{Ca}$ 13-56. All the chemicals used were of analytical grade. Gossypol standard were purchased from Sigma Chemical Company.

The results were evaluated statistically by ANOVA and tests of significance were carried out using Duncan's multiple range tests.

\section{RESULTS AND DISCUSSION}

In Table I, content of protein, oil and gossypol of cottonseed varieties are shown. The crude protein content ranged from $337.2 \mathrm{~g} \mathrm{~kg}^{-1}$ to $466.5 \mathrm{~g} \mathrm{~kg}^{-1}$. The variety of Nazilli M 39 had the lowest crude protein value $\left(337.2 \mathrm{~g} \mathrm{~kg}^{-1}\right)$, whereas the glandless variety (gossipolsüz 86) had the highest $\left(466.5 \mathrm{~g} \mathrm{~kg}^{-1}\right.$ ).

The oil content in the samples varied between the $309.7 \mathrm{~g} \mathrm{~kg}^{-1}$ and $379.5 \mathrm{~g} \mathrm{~kg}^{-1}$. The highest oil content was found in cultivars of Nazilli M 503 and Sayar 314 (379.5 g kg-1 and $371.0 \mathrm{~g} \mathrm{~kg}^{-1}$ ) respectively. Nazilli varieties had an oil content higher than the other cottonseed varieties (except Sayar 314 and NC $873 / 143)$. The variety of Nazilli 84 has been used for cultivation by producers in Aegean Region of Turkey. The glandless cottonseed variety had the lowest oil content $309.7 \mathrm{~g} \mathrm{~kg}^{-1}$ while it had very highly crude protein $466.5 \mathrm{~g} \mathrm{~kg}^{-1}$. As shown in Table II the difference in oil and protein content between the cottonseed varieties were found to be significant. This fact is attributed to the variety factor in cottonseed samples, since these varieties were grown under the same environmental conditions and at the same area in Nazilli.
Table I

Content of protein, oil and gossypol of cottonseed varieties (mean $\pm S D, n=3$ )

\begin{tabular}{lccc}
\hline Variety & Protein $\left(\mathbf{g ~ k g}^{-1}\right)$ & Oil $\left(\mathbf{g ~ k g}^{-1}\right)$ & Gossypol $\left(\mathbf{g ~ k g}^{-1}\right)$ \\
\hline Nazilli 84 & $378.3 \pm 5.10$ & $356.3 \pm 1.35$ & $8.2 \pm 0.03$ \\
Nazilli 87 & $382.8 \pm 0.50$ & $362.2 \pm 0.82$ & $7.0 \pm 0.10$ \\
Nazilli 66/100 & $372.1 \pm 6.12$ & $352.0 \pm 0.04$ & $7.8 \pm 0.23$ \\
Nazilli M 503 & $355.9 \pm 11.23$ & $379.5 \pm 0.82$ & $10.8 \pm 0.05$ \\
Nazilli M 39 & $351.1 \pm 1.92$ & $356.8 \pm 6.37$ & $8.1 \pm 0.02$ \\
Stoneville 453 & $381.5 \pm 1.10$ & $344.0 \pm 0.78$ & $12.8 \pm 0.18$ \\
NC 873/143 & $343.4 \pm 2.49$ & $365.0 \pm 0.29$ & $7.4 \pm 0.04$ \\
DPL 50 & $376.2 \pm 0.33$ & $344.2 \pm 1.80$ & $10.2 \pm 0.02$ \\
DPL 5690 & $391.2 \pm 2.74$ & $353.4 \pm 2.00$ & $10.3 \pm 0.04$ \\
Çukurova 1518 & $391.0 \pm 3.27$ & $351.7 \pm 0.78$ & $8.0 \pm 0.12$ \\
Coker 100 A/2 & $400.2 \pm 2.45$ & $329.0 \pm 1.27$ & $8.7 \pm 0.02$ \\
DPL 15/21 & $400.7 \pm 3.67$ & $350.7 \pm 1.71$ & $8.2 \pm 0.06$ \\
Erşan 92 & $396.9 \pm 7.63$ & $321.7 \pm 0.12$ & $8.7 \pm 0.04$ \\
Maras 92 & $357.6 \pm 1.39$ & $349.6 \pm 1.43$ & $7.9 \pm 0.04$ \\
Sayar 314 & $337.2 \pm 0.57$ & $371.0 \pm 1.10$ & $8.3 \pm 0.11$ \\
Gossypolsüz 86 & $466.5 \pm 1.06$ & $309.7 \pm 1.43$ & $0.2 \pm 0.03$ \\
\hline
\end{tabular}

Table II

Variance ratios (F values) of the cottonseed varieties for protein, oil and gossypol content

\begin{tabular}{lcccc}
\hline Variation source & Degree of freedom & Protein & Oil & Gossypol \\
\hline Variety & 15 & $99.51^{*}$ & $162.47^{\star}$ & $1734.7^{\star}$ \\
Error & 32 & & & \\
\hline${ }^{*} p<0.01$ & & & &
\end{tabular}

The fatty acid composition of the oils is shown in Table III. In our study, linoleic acid content of the oils obtained from different cottonseed varieties ranged the $511.9 \mathrm{~g} \mathrm{~kg}^{-1}$ and $591.5 \mathrm{~g} \mathrm{~kg}^{-1}$. Ünal and Emiroğlu (14) reported that linoleic acid content ranged from $491.0 \mathrm{~g}$ $\mathrm{kg}^{-1}$ to $581.3 \mathrm{~g} \mathrm{~kg}^{-1}$ in cottonseed oil samples obtained from some glandless cottonseed varieties.

Fatty acid composition of cottonseed oil samples were within the limits given by the Codex Alimentarius Commission (15).

As shown in Table I, the gossypol content of 15 glanded cottonseed varieties ranges between the $7.0 \mathrm{~g}$ $\mathrm{kg}^{-1}$ and $12.8 \mathrm{~g} \mathrm{~kg}^{-1}$. The highest gossypol content was observed in Stoneville 453 variety $\left(12.8 \mathrm{~g} \mathrm{~kg}^{-1}\right)$. The Nazilli 87 variety had the lowest gossypol content among the glanded varieties. As expected, one glandless variety (gossipolsüz 86 ) had the lowest value in gossypol content $\left(0.2 \mathrm{~g} \mathrm{~kg}^{-1}\right)$. Sudha and Subrahmanyam (16), studied the composition of forty commercially cultivated cottonseed varieties and found the gossypol content to be $6.4-13.2 \mathrm{~g} \mathrm{~kg}^{-1}$. Their values are similar to the values found by us. There is considerable variation in the amounts of gossypol between the cottonseed varieties and significant 
Table III

Fatty acid composition of the oils for cottonseed varieties (as $\mathbf{g ~ k g}^{-1}$ of total oil)

\begin{tabular}{lrrrrrrrrrr}
\hline Variety & $\mathrm{C}_{14: 0}$ & \multicolumn{1}{c}{$\mathrm{C}_{16: 0}$} & $\mathrm{C}_{16: 1}$ & $\mathrm{C}_{18: 0}$ & $\mathrm{C}_{18: 1}$ & $\mathrm{C}_{18: 2}$ & $\mathrm{C}_{18: 3}$ & $\mathrm{C}_{20: 0}$ & Saturated & Unsaturated \\
\hline Nazilli 84 & 8.5 & 241.0 & 8.4 & 20.4 & 164.4 & 552.6 & 4.1 & 0.6 & 270.5 & 729.5 \\
Nazilli 87 & 8.1 & 243.9 & 9.9 & 21.2 & 164.8 & 547.7 & 3.5 & 0.9 & 274.1 & 725.9 \\
Nazili 66/100 & 9.3 & 259.7 & 9.5 & 20.9 & 162.0 & 535.6 & 2.4 & 0.6 & 290.5 & 709.5 \\
Nazilli M 503 & 7.6 & 243.6 & 9.2 & 20.1 & 160.2 & 554.3 & 4.1 & 0.9 & 272.2 & 727.8 \\
Nazilli M 39 & 8.9 & 248.8 & 11.4 & 18.7 & 156.1 & 555.5 & $\mathrm{Tr}$ & 0.6 & 277.0 & 723.0 \\
Stoneville 453 & 6.7 & 201.1 & 8.8 & 19.4 & 167.6 & 591.5 & 3.3 & 1.6 & 228.8 & 771.2 \\
NC 873/143 & 7.5 & 240.8 & 10.6 & 21.0 & 164.2 & 551.4 & 3.6 & 0.9 & 270.2 & 729.8 \\
DPL 50 & 9.8 & 251.6 & 9.8 & 23.5 & 163.5 & 535.0 & 4.8 & 0.8 & 285.7 & 714.3 \\
DPL 5690 & 7.2 & 219.2 & 8.2 & 20.3 & 151.6 & 587.9 & 5.1 & 0.5 & 247.2 & 752.8 \\
Çukurova 1518 & 8.4 & 250.8 & 11.6 & 20.9 & 157.3 & 546.5 & 4.0 & 0.5 & 280.6 & 719.4 \\
Coker 100 A/2 & 8.1 & 234.0 & 9.5 & 19.7 & 153.1 & 570.6 & 4.2 & 0.8 & 262.6 & 737.4 \\
DPL 15/21 & 10.8 & 267.7 & 12.3 & 23.7 & 169.4 & 511.9 & 3.4 & 0.8 & 303.0 & 697.0 \\
Ersan 92 & 9.7 & 249.9 & 10.9 & 21.2 & 162.2 & 541.4 & 3.9 & 0.8 & 281.6 & 718.4 \\
Maras 92 & 7.7 & 229.8 & 8.7 & 20.7 & 166.8 & 562.2 & 4.1 & ND & 258.2 & 741.8 \\
Sayar 314 & 9.4 & 256.4 & 10.6 & 20.4 & 176.0 & 522.9 & 4.3 & ND & 286.2 & 713.8 \\
Gossypolsüz 86 & 9.1 & 239.6 & 9.4 & 20.3 & 139.6 & 577.2 & 4.0 & 0.8 & 269.8 & 730.2 \\
Minimum & 6.7 & 201.1 & 8.2 & 18.7 & 139.6 & 511.9 & 2.4 & 0.5 & 228.8 & 697.0 \\
Mean & 8.6 & 242.4 & 9.9 & 20.8 & 161.3 & 552.7 & 3.7 & 0.7 & 272.4 & 727.6 \\
Maximum & 10.8 & 267.7 & 12.3 & 23.7 & 176.0 & 591.5 & 5.1 & 1.6 & 303.0 & 771.2 \\
\hline
\end{tabular}

ND: Not detected

Tr: Trace

differences were found (Table II). Defatted cottonseed flour is used generally for animal nutrition. Recent years several studies were made to removal gossypol from cottonseed flour and its usage for food $(17,18$, $19,20,21)$. It was estimated that only one fourth of the cottonseed flour potentially available could satisfy the present worldwide shortage of protein (6). The use of cottonseed containing high gossypol levels were prohibited as a source of food and feed in some nations $(22,23,24)$. In the United States cottonseed protein products intended for human consumption must contain no more than $0.045 \%$ free gossypol. The Protein Advisory Group of the U.N. had sat limits of $0.06 \%$ free gossypol and $1.2 \%$ total gossypol for human consumption (22). In our study, the amount of gossypol determined in cottonseed varieties were below the limits given above. Processing will reduce the gossypol present in cottonseed meal. The resultant product would contain gossypol at lower level than raw cottonseed.

\section{ACKNOWLEDGEMENTS}

The authors are thankfull to Mr. Hasan Basri KARADAYI (Director of Cotton Research Institute of Nazilli) for providing the samples of cottonseed varieties and to Research Fund of Celal Bayar University for financial support.

\section{BIBLIOGRAPHY}

1. Anon. -«Türkiye Istatistikleri Yilliği».- T. C. Basbakanlik Devlet Istatistik Enstitüsü. D.I.E. Matbaasi, Ankara, 1990.

2. Anon. - Occurence and characteristics of oils and fats» in "The Lipid Handbook».- ed. Frank, D. G.; John, L. H. and Fred, B. P. Chapman and Hall Ltd, London (1986) 55-112.

3. E. Bernardini. - "Oilseeds and Characteristics» in "The New Oil and Fat Technology".- Revised Edition, Publishing House. Technologie s.r.l., Rome (1973) 69113.

4. M.S. Kuk, R. J. Hron, S. and G. Abraham. -«Adsorbtive gossypol removal».- Journal of American Oil Chemists' Society 70 (1993) 209-210.

5. S.A. Abou-Donia, M.J. Lasker, M.B. Abou-Donia. -«High performance liquid chromatographic analysis of gossypol».- Journal of Chromatography 206 (1981) 606610.

6. M.B. Abou-Donia. metabolism of gossypol".- Residue reviews, 61, edited by Francis A. Gunther. Springer-Verlag New York Inc. USA, (1976) 125-160.

7. A.S. El-Nockrashy, Y. El-Shattory, A.M. Gad, A.F. Baher. - «Physical and chemical characteristics of crude and refined hydrolic and solvent extracted cottonseed oil».Grasas y Aceites 20 (1969) 286-289.

8. A.H. El Tinay, A.M. Nour, S.H. Abdel-Karim, S.O. Mahgoub. - «queous protein and gossypol extraction from glanded cottonseed flour: Factors affecting protein coagulation and gossypol content". - Food Chemistry $\mathbf{3 0}$ (1988) 19-27.

9. G.S. Fisher, F.W. Arlen, F. and J. Cherry. - «Total gossypol content of glandless cottonseed".- Journal of Agricultural and Food Chemistry 36 (1988) 42-44.

10. AOAC. - Official Methods of Analysis».- Association of Official Analytical Chemists, Washington DC 1980. 
11. IUPAC. - «Standard Methods for the Analysis of Oils, Fats and Derivatives".- $6^{\text {th }}$ Ed. Pergamon Press, Oxford, 1979.

12. AOCS. - «Method $\mathrm{Ba}$ 8-55. Official and Tentative Methods of the American Oil Chemists' Society Champaign".- IL AOCS, 1964.

13. AOCS. - «Method $\mathrm{Ca}$ 13-56. Official and Tentative Methods of the American Oil Chemists' Society Champaign».- IL AOCS, 1979.

14. K Ünal, S.H. Emiroğlu. -«Bazi gossipollü ve gossipolsüz pamuk çesitlerinin tohumlarinda yağ asitleri üzerinde bir arastirma».- E.Ü.Z.F. Dergisi 20 (1983) 55-62.

15. Anon. - "Codex Committee on Fats and Oils".- Codex Alimentarius Commission CAC/RS 33-1970. Rome: Food and Agriculture Organization. World Health Organization, 1970.

16. S.P. Sudha, V.V.R. Subrahmanyam. - «Compositional studies on cottonseed and it's oil».- Journal of the Oil Technologists Association of India 19 (1987) 38-40.

17. V.I.X. Hie, P.H. Eaves, H.K. Gardner, M.G. Lambou. - ¿Degossypolized cottonseed flour-The liquid cyclone process".- Journal of the American Oil Chemists' Society (1971) 611-615.

18. A.S. El-Nockrashy, A. Hamdy-Khalil, A.M. Gad. "Degossypolization of cottonseed meal. III. Chemical and nutritional evaluation of ammonia and ferrous sulphate treated cottonseed meal».- Grasas y Aceites 23 (1972) 427-431.

19. H. Mayorga, J. González, J.F. Menchu, C. Rolz. - «Preparation of a low free gossypol cottonseed flour by dry and continuous processing".- Journal of Food Science 40 (1975) 1270-1274.

20. S.S. Mohammed. - «Effect os some gossypolization treatments of cottonseed meal on it's functional properties».- Grasas y Aceites 44 (1993) 279-283.

21. N.A.M. Eskin, D. Akomas, M. Latta. - "A study of gossypol reduction by choline and ethanolamine using a model system».- Food Chemistry 52 (1995) 43-46.

22. A.J. Lynn. - "Gossypol and some other terpenoids, flavonoids and phenols that affect quality of cottonseed protein".- Journal of American Oil Chemists' Society 56 (1979) 727-730.

23. F. Malek, P. Zandi. - «Determination of free gossipol in Iranian cottonseed and cottonseed cake".- Food Chemistry 37 (1990) 289-295.

24. J.H. Schmidt. - «An improved high performance liquid chromatographic method for detecting and quantifying terpenoids and heliocides in cottonseed".- LC-GC 7 (1989) 964-968.

Recibido: Junio 1997 Aceptado: Septiembre 1997 